\title{
IMPACT OF NEONICOTINOID INSECTICIDES RESIDUES APPLIED AS SEED TREATMENTS ON MAIZE AND ON BEES AND HIVE PRODUCTS
}

\author{
Amuza Angela Cristina ${ }^{1}$, Zaharia Roxana ${ }^{1 *}$, Gheorghe Alin ${ }^{1}$, Georgescu Emil ${ }^{2}$, Trasca \\ Georgeta $^{3}$, Podea Maria ${ }^{3}$, Pintilie Paula Lucelia ${ }^{4}$, Sapcaliu Agripina ${ }^{5}$, Mincea Carmen $^{1}$
}

${ }^{1}$ Research-Development Institute for Plant Protection, Bucharest

${ }^{2}$ National Agricultural Research and Development Institute, Fundulea

${ }^{3}$ Agricultural Research and Development Station, Pitesti.

${ }^{4}$ Agricultural Research and Development Station, Secuieni.

${ }^{5}$ Research - Development Apiculture Institute, Bucharest.

*Corresponding author:

Research-Development Institute for Plant Protection,

8 Ion Ionescu de la Brad, 013813, Bucharest, Romania

Phone: 004-021-2693231;

E-mail: roxyanna_21@yahoo.com

http://www.doi.org/10.54574/RJPP.14.13

\begin{abstract}
Romania registered in the last years record productions for maize, being in 2019, on the first place in Europe and also, according to Eurostat data, the eighth agricultural power in Europe. The European Commission closely monitors the possible relations between bee health and pesticides and is determined to take the most cautious approach possible to protect bees. In 2013, the European Commission severely restricted the use of plant protection products for seed treatment and treated seeds containing three neonicotinoids (clothianidin, imidacloprid and thiamethoxam) in order to protect honeybees (Regulation (EU) No 485/2013). Due to the restrictions imposed on Romanian farmers, they are facing an alarming increase in the population density of some soil pests, the most dangerous being Tanymecus dilaticollis and Agriotes spp., no other insecticides being available for maize seed treatment against $T$. dilaticollis in Romania. In this context, since 2018, the Ministry of Agriculture and Rural Development together with the Academy of Agricultural and Forestry Sciences funded researches to monitor populations of $T$. dilaticollis and Agriotes spp., but also the residues level of neonicotinoid insecticides from soil, plants in various development stages (leaves and inflorescences), as well as in bees and hive products (pollen, honey). Studies were performed in three areas of Romania, respectively, Moldova (Neamt County) and south of country (Calarasi County) where $T$. dilaticollis exceed the economic damage threshold (4-5 adults/sqm) and Subcarpathian hills (Arges county), where Agriotes spp. populations exceed the economic damage threshold (2-4 larvae/sqm), areas where maize is the main crop. Regarding the evolution of maize leaf weevil an wireworms population in the period 2018-2020, from the data obtained it can be observed that the number of adults/sqm has remained above the economic damage threshold. Regarding neonicotinoids residues monitoring, the samples were taken from maize crops at various growth stages, including inflorescences, from bees, pollen and honey samples, too. Residues levels were determined in accredited laboratories from Germany, France and Bulgaria using certificated methods. Of the total samples, most with residues content above LOQ (limits of quantification), are soil samples, an absolutely normal situation, as the neonicotinoids were applied as seed treatment. It is also very important to mention that the lowest percentage of samples with residues above the limit of quantification, was recorded in inflorescences, honey and bees samples, the annual deviations being insignificant. It has to be highlighted that the environmental factors, especially the humidity, influenced the repeatability of the results (for example: the rainfalls during the sowing period favored the toxic substances levigation in soil).
\end{abstract}

Key words: Neonicotinoids, soil pests, insecticide residues, seed treatment

\section{INTRODUCTION}

Romania is one of the largest maize producers in the European Union and harvested almost 8.5 million tons in 2019 (Eurostat database, 2019). Given the importance of this crop, the need to apply the seeds treatments with neonicotinoids against Tanymecus dillaticolis and 
Agriotes spp. pests is imperative (Badiu, 2019; Georgescu, 2021). Because of the problems facing Romanian agriculture due to the restriction of three neonicotinoid insecticides, imidacloprid, clothianidin and thiamethoxam, for the treatment of maize seeds, it is necessary to conduct research on their influence on crop yields. Although studies on how neonicotinoids have affected bees have not been conclusive (Matsumoto, 2013), European regulators have said the risks are too high, and so, since 2013, a restriction on the use of the insecticides in question has been imposed.

The aim of our study was to monitor and evaluate the impact of neonicotinoids seed treatment on pest control and also to establish the level of neonicotinoid residues in soil, plants, and dead bees and hive products.

\section{MATERIAL AND METHODS}

The survey of neonicotinoid seed treatment with imidacloprid, clothianidin and thiamethoxam, is conducted since 2018 and it is still ongoing, the experimental plots being located in three representative areas of Romania for maize crop, respectively Agricultural Research and Development Station Pitesti (Figures 1and 2), National Agricultural Research and Development Institute Fundulea (Figure 3) and Agricultural Research and Development Station Secuieni (Figure 4).

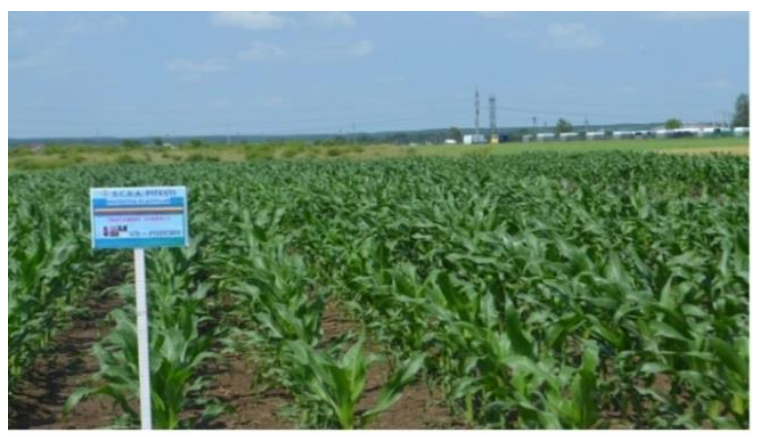

Figure 1. ARDS Pitesti experimental field

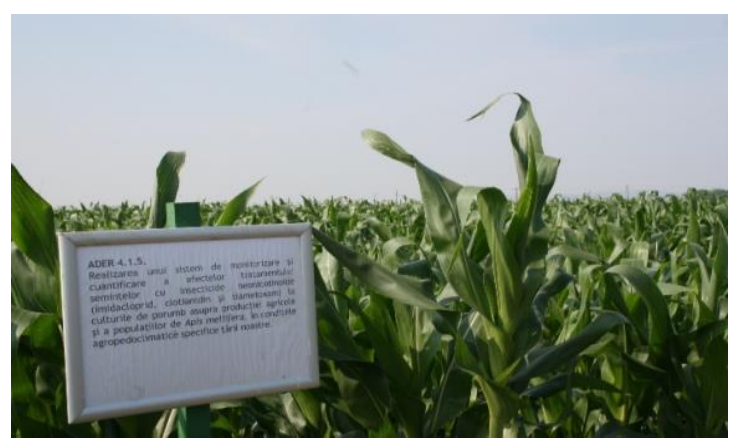

Figure 3. ARDS Secuieni experimental field

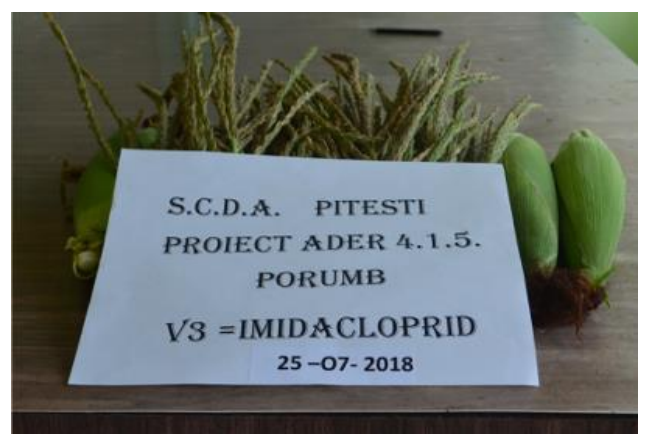

Figure 2. Maize samples at ARDS Pitesti

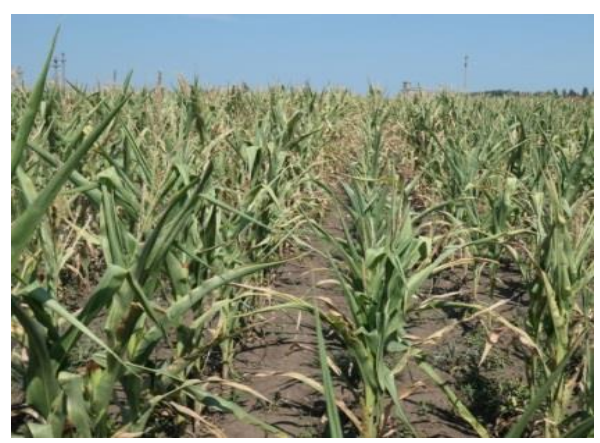

Figure 4. NARDI Fundulea experimental field

The samples were collected according to the procedure developed within a previous project, respectively: the soil sampling was made with a frame of $25 / 25 \mathrm{~cm}$, at a depth of 40 $\mathrm{cm}$ from 10 points located on the experimental plot diagonal. It were collected also samples of plant in various development stages and panicle samples, from 10 points located on the experimental plot diagonal, too. Collections and determinations of biological material were performed weekly. All samples were labeled (location, date of collection) and sent for analysis of neonicotinoid residues level. During the flowering period of the maize crop, it were collected 
also samples of pollen (Figure 5) from the beehive, using a pollen collector. All samples were stored in freezers and maintained at $-25^{\circ} \mathrm{C}$ temperature, until shipment to Bulgaria (Primoris laboratory), France (ANSES laboratory) and Germany (QSI laboratory). The method used to determine the residue level was "Multi-residues method with LC-MSMS for compounds, isomers and degradation products quantification of pesticides in fruits, vegetables, potatoes, cereals, soil and water".

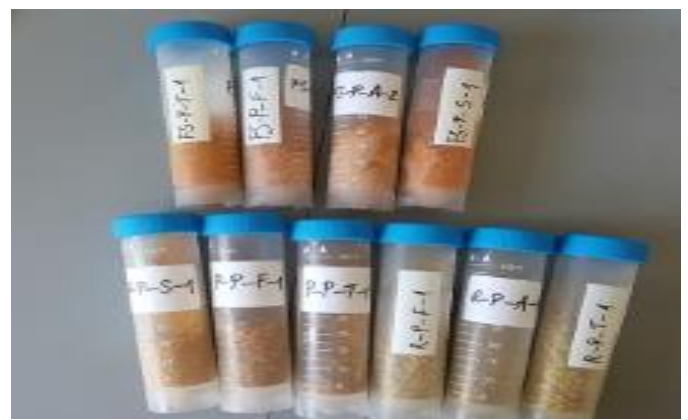

Figure 5. Maize pollen grains

The climate during the conducted survey, respectively between 2018 and 2020, was atypical, the temperature and rainfall deviations from the multiannual averages being significant. The climatic conditions greatly influenced the research in the three locations. The degree of attack produced by the T.dilaticollis species, in the spring of 2020, was very high, respectively $25.49 \%$ for the untreated control and between $0.99 \%$ and $18.13 \%$ for the treated variants. The area of the Subcarpathian Hills, respectively the experimental field of ARDS Pitești, was characterized by the high density of the population of Agriotes spp., exceeding the economic damage threshold.

\section{RESULTS AND DISCUSSIONS}

Studies conducted in the period 2018-2020 within all three experimental areas, on maize crop treated with imidacloprid, thiamethoxam and clothianidin, have established the following:

In 2018, from all analyzed samples, neonicotinoid residues were traced in maize plants, respectively, 1 sample containing clothianidin $0.013 \mathrm{mg} / \mathrm{kg} ; 2$ samples containing thiamethoxam $0.011 \mathrm{mg} / \mathrm{kg}$ and $0.052 \mathrm{mg} / \mathrm{kg} ; 1$ sample containing imidacloprid $0.010 \mathrm{mg} / \mathrm{kg}$. Also, 3 pollen samples had imidacloprid residues of $0.0011 \mathrm{mg} / \mathrm{kg}, 0.0012 \mathrm{mg} / \mathrm{kg}$, and 0.0014 $\mathrm{mg} / \mathrm{kg}$.

Regarding the level of neonicotinoid residues, in the samples of pollen and plant from ARDS Secuieni and ARDS Pitești, it was above LOQ (Limit of Quantification) in the variant of maize treated with imidacloprid. The soil samples collected from the NARDI Fundulea experimental field did not show any residues above LOQ.

In 2019, from the total amount of 34 samples, only 7 samples (20.59\%) registered neonicotinoid residues above the limit of quantification. In the 9 samples from ARDS Secuieni, consisting on plants in the BBCH stage 5-20 and panicles at full bloom, with pollen, no residues above LOQ were identified, which demonstrates that imidacloprid and clothianidin active substances identified in the soil samples were not uptaken by the plant. Six samples were collected from ARDS Pitesti, were plants with soil in which imidacloprid and clothianidin residues were identified in one sample, probably due to the presence of soil in the samples. No neonicotinoid residues were identified in the cob samples. In the 11 samples from NARDI Fundulea, which consisted in leaves and cobs, no residues above LOQ were identified. 
In 2020, residues above the limit of quantification have been identified, as follows: in plant samples, imidacloprid and thiamethoxam were identified in several samples from ARDS Secuieni (imidacloprid), ARDS Pitesti (imidacloprid and thiametoxam) and from NARDI Fundulea (imidacloprid and thiametoxam). The analysis of all samples concluded the following: out of the total amount of 63 samples, 9 samples (14.29\%) contained pesticide residues, of the 9 samples, 6 samples contained imidacloprid and thiamethoxam residues above the limit of quantification.

The results are summarized in the Table 1. During of the three years of studies, it were collected 117 samples, from these, only 23 samples (19.66\%) contained residues of imidacloprid, clothianidin and thiamethoxam above the limit of quantification (LOQ). According to the data presented in this Table 1, it can be concluded that in all the maize samples containing residues of the investigated neonicotinoids, the residues values for imidacloprid, clothianidin, thiamethoxam were under the maximum residue levels for maize established by EU regulations.

Table 1. Residue levels of imidacloprid, clothianidin and thiametoxam

\begin{tabular}{|c|c|c|c|c|c|c|}
\hline \multirow[b]{2}{*}{$\begin{array}{l}\text { Type of } \\
\text { tests }\end{array}$} & \multicolumn{2}{|r|}{2018} & \multicolumn{2}{|r|}{2019} & \multicolumn{2}{|r|}{2020} \\
\hline & $\begin{array}{c}\text { Total } \\
\text { samples }\end{array}$ & $\begin{array}{c}\% \text { samples > } \\
\text { LOQ }^{*}\end{array}$ & $\begin{array}{c}\text { Total } \\
\text { samples }\end{array}$ & $\begin{array}{c}\% \text { samples }> \\
\text { LOQ }^{*}\end{array}$ & $\begin{array}{c}\text { Total } \\
\text { samples }\end{array}$ & $\begin{array}{c}\% \text { samples > } \\
\text { LOQ }^{*}\end{array}$ \\
\hline Soil & - & - & 10 & 10 (1 sample) & 19 & 15.79 (3 samples) \\
\hline Plant & 14 & 28.57 (4 samples) & 21 & 28.57 (6 samples) & 33 & 18.18 (6 samples) \\
\hline Cob & - & - & 3 & 0 & 11 & 0 \\
\hline Pollen & 3 & 100 (3 samples) & - & - & - & - \\
\hline Total & 17 & 41.18 (7 samples) & 34 & 20.59 (7 samples) & 63 & 14.29 (9samples) \\
\hline
\end{tabular}

$*$ LOQ $=0.01 \mathrm{mg}$ a.s./kg sample

It has to be mentioned that values for maximum residues limits (MRL) for maize (Imidacloprid $=0.1 \mathrm{mg} / \mathrm{kg}$; Clothianidin $=0.02 \mathrm{mg} / \mathrm{kg}$; Thiametoxam $=0.05 \mathrm{mg} / \mathrm{kg}$ and for pollen are at least two times higher than LOQ: Imidacloprid $=0.05 \mathrm{mg} \mathrm{s.a.} / \mathrm{kg}$; Clothianidin $=$ $0.05 \mathrm{mg}$ s.a. $/ \mathrm{kg}$; Thiametoxam $=0.05 \mathrm{mg}$ s.a. $/ \mathrm{kg}$.

Honeybees and their products are potentially exposed to several contaminants present in the environment, such as chemical products released into the hive to fight against diseases and parasites and pesticides used in agriculture against pests (Aliouane et al., 2009). Neonicotinoid insecticides are successfully applied to control pests in a variety of agricultural crops; however, they may not only affect pest insects but also non-target organisms such as pollinators (Blacquiere et al., 2012). There are more than 15 years of research on the hazards of neonicotinoids to bees including honey bees, bumble bees and solitary bees, one of the most key aspects, being the environmental neonicotinoid residue levels in plants, bees and bee products in relation to pesticide application. Many lethal and sublethal effects of neonicotinoid insecticides on bees have been described in laboratory studies, however, no effects were observed in the field studies with field dosages. As an effective and economical chemical measure to prevent the attack of $T$. dillaticolis and Agriotes spp., the seed treatment is frequently used depending on the EDT. Pest control starts from the moment when the economic damage threshold is exceeded, which expresses the level of attack or density that produces damages equal to the cost of treatment and is located at the level of 3-5\% of production, depending on the crop plant. T. dillaticolis causes the greatest damage in the adult phase, the population density exceeding EDT (Economic Damage Threshold) in the South and East of Romania, areas where it is necessary to treat the seeds with neonicotinoids. In the area of the Subcarpathian Hills the most important pest is Agriotes spp. (Coleoptera-Elateridae) (Trotus, 2021).The larvae of elaterids, popularly known as "wireworms", are the main group of harmful 
insects of corn crops, manifesting themselves with a special virulence, with the most serious consequences, due to the polyphagous diet. Adults are not harmful, however, the larvae affect maize crops, the damage sometimes reaching the compromise of crops where the density of plants per $\mathrm{m}^{2}$ is low, which causes a migration and a high concentration of larvae on grains and seedlings. In maize, both the germinating grains are affected, the larvae consuming their entire contents, leaving only the shell that no longer germinates, as well as the plants up to the phase of 3-5 leaves where the larvae produce galleries in the package area, they dry and perish and many gaps are recorded in crops. In experimental maize fields from ARDS Secuieni and NARDI Fundulea, the plants were affected by wireworms' larvae of the genus Agriotes and the attack degree of $T$. dilaticollis adults was very high. The highest attack produced by Agriotes spp. was recorded in the seed in emergence and was $29 \%$ in the untreated control and between $3 \%$ and $27 \%$ in the treated variants. Regarding residues level the results showed that only 19.66 $\%$ of samples registered residues $>$ LOQ.

\section{CONCLUSIONS}

The results established the need to apply seed treatments with neonicotinoid insecticides for corn in agro-pedoclimatic conditions in Romania, unique in Europe, in terms of abundance and density of pests of this crop like Agriotes spp. and Tanymecus dilaticollis.

Regarding the residues level, the highest percentage it was registered in the soil samples. The statistical analysis shows very low variability between annual samples, most samples being, in terms of residues, below the limit of quantification. Of the total samples, most with residues content above LOQ, are soil samples, an absolutely normal situation, as the neonicotinoids were applied as seed treatment. It is also very important to mention that the lowest percentage of samples with residues above the limit of quantification, was recorded in inflorescences, honey and bees samples, the annual deviations being insignificant. It has to be highlighted that the environmental factors, especially the humidity, influenced the repeatability of the results (for example: the rainfalls during the sowing period favored the toxic substances levigation in soil). At the same time, it is necessary to continue research on the influence of pesticide treatments on honey bees and hive products.

The Ministry of Agriculture issued, on 17 January 2020, authorizations for the temporary use of this three active substances for the treatment of maize seeds just for one year. It is imperative to extend the authorization for use this active substances in the following years since no other effective active substances against Agriotes spp. and T. dilaticollis are available.

\section{ACKNOWLEDGEMENTS}

These studies were performed with founds from Ministry of Agriculture Research and Development and Foundation of the Academy of Agricultural and Forestry Sciences.

\section{REFERENCES}

ALIOUANE, Y., ADESSALAM, K.H., GARY, V., ARMENGAUD, C., LAMBIN, M., GAUTHIER, M. (2009). Subchronic exposure of honeybees to sublethal doses of pesticides: Effects on behavior. Environmental Toxicology and Chemistry, 28, 1, 113-122, doi:10.1897/08-110.1.

BADIU, A., IAMANDEI, M., GEORGESCU, E., TROTUS,, E., (2019). Studiu privind comportarea populațiilor de Tanymecus sp. în unele locații din România în perioada 2010-2018. Acta Agricola Romanica, 1, 1, 108-136.

BLACQUIËRE, T., SMAGGHE, G., VAN GESTEL, C., MOMMAERTS, V., (2012). Neonicotinoids in bees: a review on concentrations, side-effects and risk assessment. Ecotoxicology 21, 973-992, doi:10.1007/s10646-012-0863-x. 
EFSA, (2018). Evaluation of the emergency authorizations granted by Member State Romania for plant protection products containing clothianidin, imidacloprid or thiamethoxam, APPROVED: 14 May 2018 doi:10.2903/sp.efsa.2018.EN-1416.

GEORGESCU, E., TOADER, M., CANA, L., HORHOCEA, D., MANOLE, T., ZAHARIA, R., RISNOVEANU, L. (2021). Research concerning the effectiveness of the maize foliar treatment compared with seeds treatment for chemical control of the maize leaf weevil (Tanymecus dilaticollis Gyll) in the south-east of Romania. Romanian Agricultural Research, 38, 357-369.

LAURINO, D., PORPORATO, M., PATETTA, A., MANINO, A. (2011). Toxicity of neonicotinoid insecticides to honey bees: laboratory tests. Bulletin of Insectology, 64, 1, 107-113.

MATSUMOTO, T. (2013). Reduction in homing flights in the honey bee Apis Mellifera after a sublethal dose of neonicotinoid insecticides. Bulletin of Insectology, 66, 1-9.

OECD, (2009), Guidance document on the definition of residues, ENV/JM/MONO 30.

KILJANEK, T., NIEWIADOWSKA, A., POSYNIAK, A. (2016). Pesticide Poisoning of Honeybees: A Review of Symptoms, Incident Classification, and Causes of Poisoning. Journal of Apicultural Science, 60, 2, 5-24.

TROTUS, E., PINTILIE, L.P., AMARGHIOALEI, R.G. (2021). Protectia culturilor de porumb impotriva bolilor si daunatorilor. Ed. Ion Ionescu de la Brad, Iasi, 5-161, ISBN 978-973-147-420-5.

Commission Implementing Regulation (EU) No 485/2013 of 24 May 2013 amending Implementing Regulation (EU) No 540/2011, as regards the conditions of approval of the active substances clothianidin, thiamethoxam and imidacloprid, and prohibiting the use and sale of seeds treated with plant protection products containing those active substances;

Eurostat Statistics Explained, 2019. Available from https://ec.europa.eu/eurostat/statistics-explained/ index.php/Agricultural production - crops. 